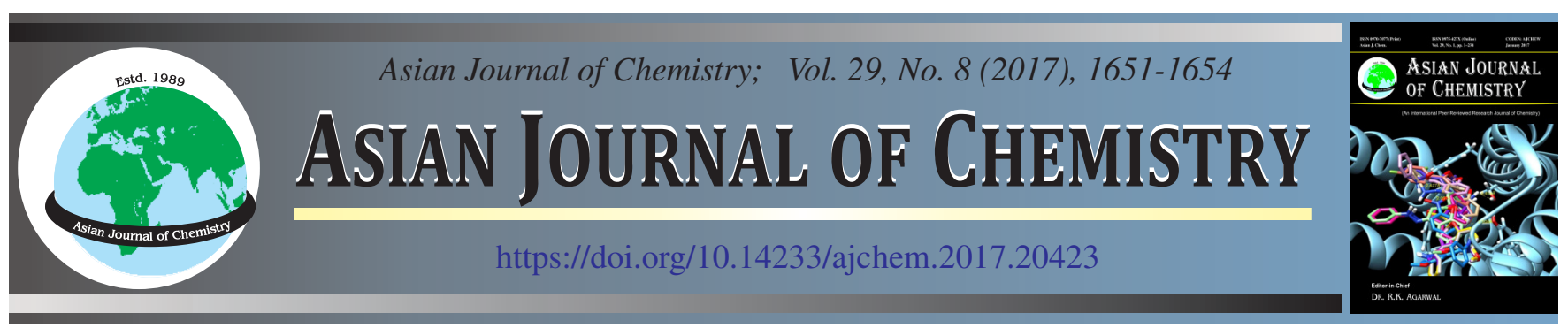

\title{
Synthesis of Substituted 2-Phenyl-1H-indoles and their Fungicidal Activity
}

\author{
Geetika Arora $^{1, *}$, Sunita Sharma ${ }^{2}$ and Sukesha Joshi ${ }^{1}$
}

\author{
${ }^{1}$ Department of Chemistry, Punjab Agricultural University, Ludhiana-141 004, India \\ ${ }^{2}$ Department of Plant Breeding and Genetics, Punjab Agricultural University, Ludhiana-141 004, India \\ *Corresponding author: E-mail: geet2487@gmail.com
}

\section{INTRODUCTION}

Heterocyclic compounds form a special class of cyclic organic compounds in which atleast one of the carbon atoms are replaced by heteroatoms like oxygen, nitrogen and sulphur, etc. These compounds are known to possess variety of bioactivities like antifungal, anticancer, antiviral and antimicrobial [1-4] etc. Indoles, also known as benzpyrrole are aromatic nitrogen heterocycles of prime importance containing fused benzene and pyrrole rings. Firstly synthesized by Baeyer and Emmerling [5] from oxindole using zinc dust, indoles have been synthesized by various methods such as catalytic reduction of $o$-nitrotoluenes [6], anilines and $\alpha$-haloketones [7,8], cyclization of $o$-allylanilines [9] and Pd catalyzed coupling of alkynes with substituted iodoanilines [10]. But the Fischer indole synthesis remains the most popular method involving the condensation of phenyl hydrazines with substituted aldehydes or ketones followed by cyclization conventionally [11] as well as under microwave irradiation [12]. Indoles have registered their presence in variety of natural and synthetic compounds. Some of the naturally occurring indole derivatives include indole-3-acetic acid which is a plant growth hormone and tryptophan-derived tryptamine alkaloids like neurotransmitters i.e. serotonin and melatonin. Indoles regulate physiological aspects in bacterial cells primarily including spore formation, drug resistance along with plasmid formation and virulence [13]. Indoles also form a part of drugs like indomethacin (which is used as an anti-inflammatory, an antipyretic and an analgesic), indoxole (an anti-inflammatory and anti- pyretic) and the naturally occurring hallucinogen dimethyltryptamine (N,N-DMT). Indoles and its derivatives are known to posses biological activities e.g., anticancer, antifungal, anticonvulsant, anti-inflammatory and analgesic [2,14-16] etc.

Keeping in view the bioactivity of indoles, present work was carried out for the synthesis of 2-phenyl- $1 H$-indole derivatives and investigation of their antifungal activity.

\section{EXPERIMENTAL}

Purity of compounds was estimated by thin layer chromatography. The melting points were recorded on electrical melting point apparatus in open capillaries and are uncorrected. Structural confirmation of the compounds was made on the basis of spectral analysis. UV spectra were scanned from Shimadzu UV 1800 using DMSO as solvent. IR, ${ }^{1} \mathrm{H}$ NMR and ${ }^{13} \mathrm{C}$ NMR spectra were got scanned from Sophisticated Analytical Instrumentation Facility (SAIF), Central Instrument Laboratory (CIL), Panjab University, Chandigarh. The IR spectra were recorded using $\mathrm{KBr}$ discs on Perkin-Elmer FTIR spectrophotometer with $\lambda_{\max }\left(\mathrm{cm}^{-1}\right)$. NMR spectra were recorded on a Bruker Avance II $400 \mathrm{MHz}$ instrument using TMS as an internal standard. The chemical shifts were expressed in $\delta$ (ppm) values. All the compounds gave satisfactory $\mathrm{C}, \mathrm{H}, \mathrm{N}$ and $\mathrm{S}$ analysis that was recorded on Vario EL III Elementor CHNS analyzer.

Synthesis of 2-phenyl-1H-indoles (1-5): Substituted acetophenone $(0.01 \mathrm{~mol})$ was added to solution of phenyl hydrazine $(0.01 \mathrm{~mol})$ in $(5 \mathrm{~mL})$ absolute ethanol in a $100 \mathrm{~mL}$ 
conical flask. The reaction mixture was stirred for $15 \mathrm{~min}$ at room temperature followed by the addition of 2 drops of glacial acetic acid as catalyst. The reaction mixture was warmed on water bath for $15 \mathrm{~min}$ and was then cooled in beaker containing ice to afford crystals of respective hydrazones. The crude hydrazones were then dried. Polyphosphoric acid (10 g) was taken in a $150 \mathrm{~mL}$ beaker and synthesized hydrazones were added in small lots to the acid with constant stirring on boiling water bath. The mixture was further stirred for about $20 \mathrm{~min}$. The hot solution was then poured in a beaker containing ice cold water which resulted in the formation of precipitates. The precipitation was further completed by stirring the mixture for 10-15 min. The crude product so formed was allowed to settle and then filtered. The product was washed with cold methanol and allowed to dry. The product was recrystallized by dissolution in hot ethanol and addition of activated charcoal $(0.1 \mathrm{~g})$ and was filtered hot. The filtrate was reheated to boiling and water was added to cloudy point. The ethanol was added dropwise to redissolve the cloudy precipitates and the solution was allowed to cool at room temperature. Physical data of all the synthesized compounds have been recorded (Table-1).

\begin{tabular}{cllccc}
\multicolumn{7}{c}{ TABLE-1 } \\
\multicolumn{7}{c}{ PHYSICAL PARAMETERS OF } \\
\hline $\begin{array}{c}\text { Compd. } \\
\text { No. }\end{array}$ & m.f. & Colour & $\begin{array}{c}\text { Yield } \\
(\%)\end{array}$ & $\mathrm{R}_{\mathrm{f}}^{\mathrm{a}}$ & $\begin{array}{c}\text { m.p. } \\
\left({ }^{\circ} \mathrm{C}\right)\end{array}$ \\
\hline $\mathbf{1}$ & $\mathrm{C}_{15} \mathrm{H}_{13} \mathrm{~N}$ & Off white & 28 & 0.86 & $212-213$ \\
$\mathbf{2}$ & $\mathrm{C}_{14} \mathrm{H}_{10} \mathrm{NCl}$ & Off white & 78 & 0.83 & $200-201$ \\
$\mathbf{3}$ & $\mathrm{C}_{14} \mathrm{H}_{10} \mathrm{NBr}$ & Off white & 75 & 0.91 & $214-215$ \\
$\mathbf{4}$ & $\mathrm{C}_{14} \mathrm{H}_{10} \mathrm{~N}_{2} \mathrm{O}_{2}$ & Off white & 68 & 0.85 & $166-167$ \\
$\mathbf{5}$ & $\mathrm{C}_{14} \mathrm{H}_{10} \mathrm{~N}_{2} \mathrm{O}_{2}$ & Light brown & 72 & 0.73 & $170-171$ \\
\hline
\end{tabular}

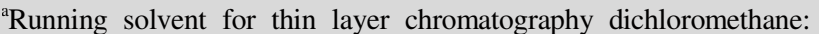
petroleum ether (50:50)

Testing of fungicidal activity: Synthesized 2-phenyl- $1 H$ indoles (1-5) were evaluated for their in vitro antifungal activity against $R$. solani and $F$. monilliforme by poisoned food technique [17] using DMSO as control and bavistin as standard. The per cent inhibition and $\mathrm{ED}_{50}$ of synthesized compounds against both the test fungi was determined.

2-(4-Tolyl)-1H-indole (1): Yield $28 \%$, m.p. $212-213{ }^{\circ} \mathrm{C}$. UV $\left(\lambda_{\max }, \mathrm{nm}\right) 284.5$, IR (KBr, $\left.v_{\max }, \mathrm{cm}^{-1}\right): 3470$ (N-H str.), 3070 (Ar C-H str.), 2856, 2966 (aliphatic C-H str.), 1570 (Ar. C-C str.), 1240 (C-N str.), 720 (N-H bending). ${ }^{1} \mathrm{H}$ NMR (400 $\left.\mathrm{MHz}, \mathrm{CDCl}_{3}, \delta \mathrm{ppm}\right): 11.48$ (s, 1H), 7.76-7.74 (2H, d, Ar-H, $J=8.2 \mathrm{~Hz}), 7.72-7.69(1 \mathrm{H}, \mathrm{d}, \mathrm{Ar}-\mathbf{H}, J=7.4 \mathrm{~Hz}), 7.41-7.38$ $(1 \mathrm{H}, \mathrm{d}, \mathrm{Ar}-\mathbf{H}, J=7 \mathrm{~Hz}), 7.27-7.25(2 \mathrm{H}, \mathrm{d}, \mathrm{Ar}-\mathbf{H}, J=8.2 \mathrm{~Hz})$, 7.21-7.18 (1H, t, Ar-H, $J=7.2$ Hz), 7.01-6.99 (1H, t, Ar-H, $J$ $=7.2 \mathrm{~Hz}), 6.86(\mathrm{~s}, 1 \mathrm{H},-\mathrm{CH}=), 2.34\left(3 \mathrm{H}, \mathrm{s}, \mathrm{CH}_{3}\right) .{ }^{13} \mathrm{C} \mathrm{NMR}$ (100 MHz, $\left.\mathrm{CDCl}_{3}, \delta \mathrm{ppm}\right) 137.11-115.14$ (aromatic carbons), $98.70(-\mathrm{CH}=), 21.3\left(-\mathrm{CH}_{3}\right)$. Anal. calcd. $(\%)$ for $\mathrm{C}_{15} \mathrm{H}_{13} \mathrm{~N}: \mathrm{C}$, 86.95; H, 6.28; N, 6.76. Found (\%): C, 86.97; H, 6.30; N, $6.72 \%$.

2-(4-Chlorophenyl)-1H-indole (2): Yield $78 \%$, m.p. 200$201{ }^{\circ} \mathrm{C}$. UV $\left(\lambda_{\max }, \mathrm{nm}\right) 285.5, \mathrm{IR}\left(\mathrm{KBr}, \nu_{\max }, \mathrm{cm}^{-1}\right): 3432(\mathrm{~N}-\mathrm{H}$ str.), 3081 (Ar C-H str.), 1570 (Ar C-C str.), 1228 (C-N str.), 750 (C-Cl str.), 723 (N-H bending). ${ }^{1} \mathrm{H}$ NMR (400 MHz, $\left.\mathrm{CDCl}_{3}, \delta \mathrm{ppm}\right): 11.51(1 \mathrm{H}, \mathrm{s}, \mathrm{NH}), 7.86-7.84(2 \mathrm{H}, \mathrm{d}, \mathrm{Ar}-\mathbf{H}, J$
$=8.6 \mathrm{~Hz}), 7.53-7.51(1 \mathrm{H}, \mathrm{d}, \mathrm{Ar}-\mathbf{H}, J=7.8 \mathrm{~Hz}), 7.47-7.45(2 \mathrm{H}$, d, Ar-H, $J=8.6 \mathrm{~Hz}), 7.40-7.38(1 \mathrm{H}, \mathrm{d}, \mathrm{Ar}-\mathbf{H}, J=7.44 \mathrm{~Hz})$, 7.11-7.07 (1H, t, Ar-H, $J=7.84 \mathrm{~Hz}), 7.01-6.97(1 \mathrm{H}, \mathrm{t}, \mathrm{Ar}-\mathbf{H}$, $J=7.84 \mathrm{~Hz}), 6.86(\mathrm{~s}, 1 \mathrm{H},-\mathrm{CH}=) .{ }^{13} \mathrm{C} \mathrm{NMR}\left(100 \mathrm{MHz}, \mathrm{CDCl}_{3}\right.$, $\delta \mathrm{ppm}$ ) 137.11-111.16 (aromatic carbons), 98.90(-CH=). Anal. calcd. (\%) for $\mathrm{C}_{14} \mathrm{H}_{10} \mathrm{NCl}$ : C, 73.85; H, 4.39; N, 6.15. Found (\%): C, 73.81; H, 5.02; N, $6.18 \%$.

2-(4-Bromophenyl)-1H-indole (3): Yield $75 \%$, m.p. 215$216{ }^{\circ} \mathrm{C}$. UV $\left(\lambda_{\max }, \mathrm{nm}\right) 285, \mathrm{IR}\left(\mathrm{KBr}, \nu_{\max }, \mathrm{cm}^{-1}\right): 3350(\mathrm{~N}-\mathrm{H}$ str.), 3050 (Ar C-H str.), 1570 (Ar C-C str.), 1242 (C-N str.), 720 (N-H bending), 501 (C-Br str.). ${ }^{1} \mathrm{H}$ NMR (400 MHz, $\left.\mathrm{CDCl}_{3}, \delta \mathrm{ppm}\right): 11.76(1 \mathrm{H}, \mathrm{s}, \mathrm{NH}), 7.77-7.75(2 \mathrm{H}, \mathrm{d}, \mathrm{Ar}-\mathbf{H}, J$ $=8.6 \mathrm{~Hz}), 7.58-7.56(2 \mathrm{H}, \mathrm{d}, \operatorname{Ar}-\mathbf{H} J=8.6 \mathrm{~Hz}), 7.52-7.51(1 \mathrm{H}$, $\mathrm{d}, \operatorname{Ar}-\mathbf{H}, J=7.9 \mathrm{~Hz}), 7.40-7.38(1 \mathrm{H}, \mathrm{d}, \mathrm{Ar}-\mathbf{H}, J=7.52 \mathrm{~Hz})$, 7.11-7.07 (1H, t, Ar-H, $J=7.83$ Hz), 7.01-6.99 (1H, t, Ar-H, $J=7.83 \mathrm{~Hz}), 6.83(1 \mathrm{H}, \mathrm{s},-\mathrm{CH}=) .{ }^{13} \mathrm{C} \mathrm{NMR}\left(100 \mathrm{MHz}, \mathrm{CDCl}_{3}\right.$, $\delta \mathrm{ppm})$ 138.21-109.14 (aromatic carbons), 98.90 (-CH=). Anal. calcd. (\%) for $\mathrm{C}_{14} \mathrm{H}_{10} \mathrm{NBr}$ : C, 61.99; H, 3.69; N, 5.17. Found (\%): C, 62.00; H, 3.68; N, $5.18 \%$.

2-(3-Nitrophenyl)-1H-indole (4): Yield $68 \%$, m.p. 166$167{ }^{\circ} \mathrm{C}$. UV $\left(\lambda_{\max }, \mathrm{nm}\right) 284.5, \mathrm{IR}\left(\mathrm{KBr}, \nu_{\max }, \mathrm{cm}^{-1}\right): 3456(\mathrm{~N}-\mathrm{H}$ str.), 3062 (aromatic C-H str.), 1578 (aromatic C-C str.), 1485 $\left(v_{\text {as }} \mathrm{N}-\mathrm{O}\right.$ str), 1335 ( $\mathrm{v}_{\mathrm{s}} \mathrm{N}-\mathrm{O}$ str), 1242 (C-N str.), $738(\mathrm{~N}-\mathrm{H}$ bending). ${ }^{1} \mathrm{H}$ NMR (400 MHz, $\left.\mathrm{CDCl}_{3}, \delta \mathrm{ppm}\right): 11.75(1 \mathrm{H}, \mathrm{s}$, NH), 8.70 (1H, s, Ar-H), 8.26-8.24 (1H, d, Ar-H, $J=7.8 \mathrm{~Hz})$, 8.11-8.09 (1H, d, Ar-H, $J=8.0$ Hz), 7.69-7.65 (1H, t, Ar-H, $J$ $=8.0 \mathrm{~Hz}), 7.57-7.55(1 \mathrm{H}, \mathrm{d}, \mathrm{Ar}-\mathbf{H}, J=7.8 \mathrm{~Hz}), 7.44-7.42$ $(1 \mathrm{H}, \mathrm{d}, \mathrm{Ar}-\mathbf{H}, J=8.1 \mathrm{~Hz}) 7.16-7.12(1 \mathrm{H}, \mathrm{t}, \mathrm{Ar}-\mathbf{H}, J=7.2$ $\mathrm{Hz}), 7.04-7.02(1 \mathrm{H}, \mathrm{t}, \mathrm{Ar}-\mathbf{H}, J=7.2 \mathrm{~Hz}), 7.00(1 \mathrm{H}, \mathrm{s},-\mathrm{CH}=)$. ${ }^{13} \mathrm{C} \mathrm{NMR}\left(100 \mathrm{MHz}, \mathrm{CDCl}_{3}, \delta \mathrm{ppm}\right.$ ): 148.11-112.45 (aromatic carbons), 98.82 (-CH=). Anal. calcd. (\%) for $\mathrm{C}_{14} \mathrm{H}_{10} \mathrm{~N}_{2} \mathrm{O}_{2}$ : C, 70.59; H, 4.20; N, 11.76. Found (\%): C, 70.61; H, 4.21; N, $11.75 \%$.

2-(4-Nitrophenyl)-1H-indole (5): Yield $72 \%$, m.p. 170$171{ }^{\circ} \mathrm{C}$. UV $\left(\lambda_{\max }, \mathrm{nm}\right) 283.5$, IR $\left(\mathrm{KBr}, \nu_{\max }, \mathrm{cm}^{-1}\right): 3451(\mathrm{~N}-\mathrm{H}$ str.), 3062 (aromatic C-H str.), 1575 (aromatic C-C str.), 1490 $\left(v_{\text {as }} \mathrm{N}-\mathrm{O}\right.$ str), 1338 ( $\mathrm{v}_{\mathrm{s}} \mathrm{N}-\mathrm{O}$ str), 1235 (C-N str.), $735(\mathrm{~N}-\mathrm{H}$ bending). ${ }^{1} \mathrm{H}$ NMR (400 MHz, $\left.\mathrm{CDCl}_{3}, \delta \mathrm{ppm}\right): 11.73(1 \mathrm{H}, \mathrm{s}$, NH), 8.26-8.24 (2H, d, Ar-H, $J=8.72 \mathrm{~Hz}), 8.06-8.04(2 \mathrm{H}, \mathrm{d}$, $\operatorname{Ar}-\mathbf{H}, J=8.72 \mathrm{~Hz}), 7.58-7.56(1 \mathrm{H}, \mathrm{d}, \mathrm{Ar}-\mathbf{H}, J=7.9 \mathrm{~Hz})$, 7.47-7.45 (1H, d, Ar-H, $J=8.0$ Hz), 7.18-7.14 (1H, t, Ar-H, $J$ $=7.8 \mathrm{~Hz}), 7.05-7.01(1 \mathrm{H}, \mathrm{t}, \operatorname{Ar}-\mathbf{H}, J=8.0 \mathrm{~Hz}), 6.49(1 \mathrm{H}, \mathrm{s}$, -CH=). ${ }^{13} \mathrm{C} \mathrm{NMR}\left(100 \mathrm{MHz}, \mathrm{CDCl}_{3}, \delta \mathrm{ppm}\right): 147.11-112.43$ (aromatic carbons), $91.70(-\mathbf{C H}=)$. Anal. calcd. (\%) for $\mathrm{C}_{14} \mathrm{H}_{10} \mathrm{~N}_{2} \mathrm{O}_{2}$ : C, 70.59; H, 4.20; N, 11.76. Found (\%): C, 70.57; $\mathrm{H}, 4.19 ; \mathrm{N}, 11.78 \%$.

\section{RESULTS AND DISCUSSION}

Synthesis of 2-phenyl- $1 H$-indoles was done by condensing substituted acetophenones namely 4-methylacetophenone, 4-chloroacetophenone, 4-bromoacetophenone, 3-nitroacetophenone and 4-nitroacetophenone with phenylhydrazine in ethanolic medium in presence of glacial acetic acid as catalyst. The crude phenylhydrazones formed were dried and were subjected to condensation under strongly acidic conditions with polyphosphoric acid (Scheme-I) to afford 2-phenyl-1 $\mathrm{H}$-indoles (1-5). 
<smiles>[R]c1ccc(C(C)=O)cc1</smiles>

95\% Ethanol

(i) 2-3 drops of acetic acid (ii) warm<smiles>[R]c1ccc(/C(C)=N/Nc2ccccc2)cc1</smiles>

1-phenyl-2-(1-phenylethylidene)hydrazine derivatives

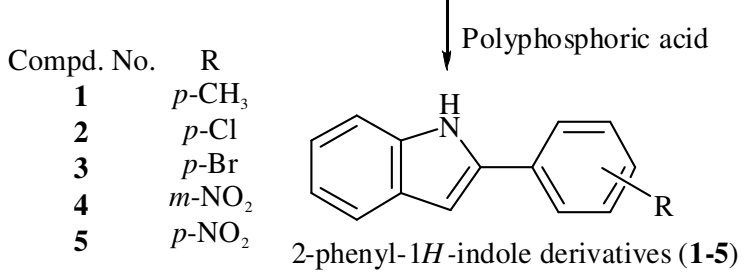

Scheme-I: Synthesis of various 2-phenyl-1 $H$-indoles (1-5)

IR data: Presence of $\mathrm{N}-\mathrm{H}$ stretching and $\mathrm{C}-\mathrm{N}$ stretching along with $\mathrm{N}-\mathrm{H}$ bending vibrations in the range of 3470-3350, 1242-1228 and 738-720 $\mathrm{cm}^{-1}$ respectively and absence of $\mathrm{C}=\mathrm{N}$ stretching vibration which is characteristic of hydrazones further confirmed cyclization and indole ring formation. Stretching bands at 2966 and $2856 \mathrm{~cm}^{-1}$ due to aliphatic C-H attributed to presence of methyl group in $\mathbf{1}$. Compound $\mathbf{2}$ and 3 exhibited characteristic stretching at 750 and $501 \mathrm{~cm}^{-1}$ which indicated the presence of $\mathrm{Cl}$ and $\mathrm{Br}$ in these compounds respectively. Bands at 1490,1485 and $1335,1338 \mathrm{~cm}^{-1}$ corresponding to asymmetric and symmetric stretching of $\mathrm{N}-\mathrm{O}$ were observed in compounds $\mathbf{4}$ and $\mathbf{5}$.

${ }^{1} \mathbf{H}$ NMR: Two singlets in the range of $\delta 11.76-11.48 \mathrm{ppm}$ due to $\mathrm{N}-\mathrm{H}$ and in the range of $\delta 6.49-7.00 \mathrm{ppm}$ due to methine proton were observed in all the synthesized compounds. All the compounds except compound $\mathbf{4}$ exhibited a pair of two proton doublets in aromatic region suggestive of para substitution in the phenyl ring. Compound $\mathbf{4}$ containing meta substitution had one proton singlet along with one proton doublet and one proton triplet. The spectra of all the compounds contained a pair of one proton doublet and one proton triplet characteristic of unsubstituted phenyl ring of indole nucleus. A singlet due to three protons at $2.34 \mathrm{ppm}$ corresponding to methyl group was present in the spectra of compound $\mathbf{1}$. Further confirmation was done on the basis of coupling constants. The coupling constants of a pair of two proton doublets of phenyl ring were found to be equivalent. Absence of three proton singlet corresponding to acetyl protons of acetophenone characteristic of hydrazone further ensured cyclization to form 2-phenyl$1 H$-indoles.

${ }^{13}$ C NMR: Presence of a peak in the range of 98.90-91.70 was suggestive of methine carbon in all the compounds. All other peaks appeared in the region 148.11-109.14 corresponding to aromatic carbons. Absence of peak above $150 \mathrm{ppm}$ indicative of carbonyl group ensured the cyclization to form indoles.
Antifungal activity: The synthesized 2-phenyl- $1 H$-indoles (1-5) were screened for their antifungal activity against two phytopathogenic fungi viz. R. solani and F. monilliforme by in vitro poisoned food technique. DMSO and bavistin respectively were used as control and standard fungicide against both the test fungi. The results has been expressed in terms of per cent inhibition and $\mathrm{ED}_{50}$ values, i.e. the effective dose at which 50 $\%$ inhibition has occurred, for all the synthesized compounds against both the test fungi.

Antifungal activity of 2-phenyl-1H-indoles against $\boldsymbol{R}$. solani: The perusal of data presented in Table- 2 indicated that all the compounds exhibited moderate to promising activity against $R$. solani even at the concentration of $50 \mu \mathrm{g} / \mathrm{mL}$ with inhibition more than $18 \%$. Compound 2 having chloro group at para position showed complete inhibition percentage 1000 $\mu \mathrm{g} / \mathrm{mL}$ while compound $\mathbf{1}$ bearing methyl group at para position registered highest per cent inhibition at the concentration of 50 and $100 \mu \mathrm{g} / \mathrm{mL}$ amongst all the test compounds. All the test compounds were found to be less effective than standard at all the concentrations with the exception of compound $\mathbf{3}$ with complete inhibition at 500 and $1000 \mu \mathrm{g} / \mathrm{mL}$. Compounds containing electron releasing groups were found to be more effective with Compound $\mathbf{1}$ bearing methyl group being most potent $\left(\mathrm{ED}_{50}\right.$ at $\left.21 \mu \mathrm{g} / \mathrm{mL}\right)$. Compounds $\mathbf{4}$ and $\mathbf{5}$ with electron withdrawing substituent were less effective, out of which compound $\mathbf{5}$ having nitro group at para position was least effective ( $\mathrm{ED}_{50}$ at $598 \mu \mathrm{g} / \mathrm{mL}$ ) (Fig. 1). None of the compound was found to be more potent than standard bavistin $\left(\mathrm{ED}_{50}\right.$ at 5 $\mathrm{mg} / \mathrm{mL}$ ) (Table-2).

TABLE-2

PERCENT INHIBITION OF VARIOUS 2-PHENYL- $1 H$-INDOLES AGAINST $R$. solani AT DIFFERENT CONCENTRATIONS $(\mu \mathrm{g} / \mathrm{mL})$

\begin{tabular}{cccccc}
\hline \multirow{2}{*}{ Compd. No. } & \multicolumn{5}{c}{ Inhibition (\%) } \\
\cline { 2 - 6 } & 50 & 100 & 250 & 500 & 1000 \\
\hline $\mathbf{1}$ & 69.16 & 72.25 & 74.51 & 80.02 & 82.51 \\
$\mathbf{2}$ & 47.50 & 59.79 & 90.40 & 99.96 & 100 \\
$\mathbf{3}$ & 51.25 & 66.25 & 68.76 & 71.25 & 77.50 \\
$\mathbf{4}$ & 24.27 & 28.35 & 40.20 & 56.22 & 62.51 \\
$\mathbf{5}$ & 18.37 & 26.87 & 43.75 & 51.25 & 58.75 \\
Bavistin & 100 & 100 & 100 & 100 & 100 \\
$\mathrm{CD}(\mathrm{p}=0.05)$ & 0.04 & 0.0002 & 0.12 & 0.0002 & 0.05 \\
\hline
\end{tabular}

Antifungal activity of 2-phenyl-1H-indoles against $\boldsymbol{F}$. monilliforme: The data presented in Table-3 revealed that all the compounds were only moderately effective against $F$. monilliforme at all the concentrations with per cent inhibition ranging from 18.61-63.82 irrespective of the substitution and the concentration. Compound $\mathbf{1}$ with methyl group at para position and compound $\mathbf{3}$ with para bromo substitution was found to most and least effective respectively at $50 \mu \mathrm{g} / \mathrm{mL}$, respectively. Both the nitro bearing compounds were found to show comparable inhibition at all the test concentrations and were most effective at $1000 \mu \mathrm{g} / \mathrm{mL}$. Compound 4 with meta nitro substitution was most effective $\left(\mathrm{ED}_{50}\right.$ at $\left.362 \mu \mathrm{g} / \mathrm{mL}\right)$ followed by 5 with para nitro group ( $\mathrm{ED}_{50}$ at $405 \mu \mathrm{g} / \mathrm{mL}$ ). Compound 2 having para chloro substitution was found to be least effective with $\mathrm{ED}_{50}$ at $851 \mu \mathrm{g} / \mathrm{mL}$. In general, the synthesized compounds had shown better control against $R$. solani 


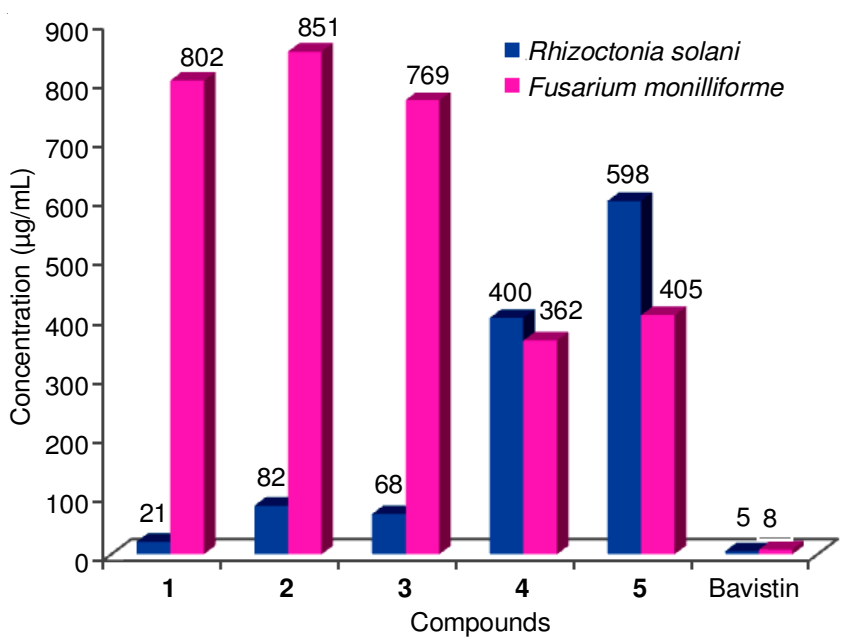

Fig. 1. $\mathrm{ED}_{50}$ of 2-phenyl-1 $H$-indoles against phytopathogenic fungi of maize

\begin{tabular}{|c|c|c|c|c|c|}
\hline \multicolumn{6}{|c|}{$\begin{array}{l}\text { PERCENT INHIBITION OF VARIOUS 2-PHENYL- } \\
1 H \text {-INDOLES AGAINST Fusarium moniliforme AT } \\
\text { DIFFERENT CONCENTRATIONS }(\mu \mathrm{g} / \mathrm{mL})\end{array}$} \\
\hline \multirow{2}{*}{ Compd. No. } & \multicolumn{5}{|c|}{ Inhibition (\%) } \\
\hline & 50 & 100 & 250 & 500 & 1000 \\
\hline 1 & 28.12 & 30.87 & 36.63 & 45.83 & 51.87 \\
\hline 2 & 23.54 & 24.58 & 31.25 & 35.62 & 54.37 \\
\hline 3 & 18.61 & 27.22 & 38.25 & 41.88 & 55.23 \\
\hline 4 & 18.66 & 23.73 & 46.24 & 60.05 & 62.91 \\
\hline 5 & 19.10 & 23.17 & 39.02 & 59.34 & 63.83 \\
\hline Bavistin & 100 & 100 & 100 & 100 & 100 \\
\hline $\mathrm{CD}(\mathrm{p}=0.05)$ & 0.04 & 0.01 & 0.0001 & 0.0002 & 0.0002 \\
\hline
\end{tabular}

over F. monilliforme. None of the compounds exhibited better potency than bavistin $\left(\mathrm{ED}_{50}\right.$ at $\left.8 \mu \mathrm{g} / \mathrm{mL}\right)$ (Table-3).

\section{Conclusion}

Substituted 2-phenyl- $1 H$-indoles were synthesized by condensing substituted acetophenones with phenyl hydrazine under slightly acidic condition to form respective phenyl hydrazones which were further subjected to ring closure using polyphosphoric acid. All the indoles exhibited $\mathrm{ED}_{50}$ less than 598 and 851 against $R$. solani and $F$. monilliforme respectively. Compound with para methyl substitution was most effective against $R$. solani while compound with meta nitro group was most effective against $F$. monilliforme. None of the compounds were found to be as effective as standard bavistin against both the test fungi.

\section{ACKNOWLEDGEMENTS}

The authors are thankful to CSIR, New Delhi, India for financial assistance, SAIF, Panjab University, Chandigarh, India for providing facilities for spectral analysis and Maize section, Department of Plant Breeding and Genetics, Punjab Agricultural University, Ludhiana, India for providing fungal cultures.

\section{REFERENCES}

1. A. Goyal, S. Sharma, J. Gaba and H. Kaur, Asian J. Chem., 28, 2169 (2016); https://doi.org/10.14233/ajchem.2016.19900.

2. P. Singh, M. Kaur and P. Verma, Bioorg. Med. Chem. Lett., 19, 3054 (2009); https://doi.org/10.1016/i.bmcl.2009.04.014.

3. I.A. Leneva, R.J. Russell, Y.S. Boriskin and A.J. Hay, Antiviral Res., 81, 132 (2009);

https://doi.org/10.1016/j.antiviral.2008.10.009.

4. J. Gaba, S. Sharma, G. Arora, S. Joshi and A. Goyal, J. Indian Chem. Soc., 92, 1587 (2015).

5. A. Baeyer and A. Emmerling, Ber. Dtsch. Chem. Ges., 2, 679 (1869); https://doi.org/10.1002/cber.186900201268.

6. R. D. Clark and D. B. Repke, Heterocycles, 22, 195 (1984); https://doi.org/10.3987/R-1984-01-0195.

7. A. Bischler and P. Fireman, Ber. Dtsch. Chem. Ges., 26, 1336 (1893); https://doi.org/10.1002/cber.18930260232.

8. R. Möhlau, Ber. Dtsch. Chem. Ges., 14, 171 (1881); https://doi.org/10.1002/cber.18810140146.

9. L.S. Hegedus, G.F. Allen and E.L. Waterman, J. Am. Chem. Soc., 98, 2674 (1976);

https://doi.org/10.1021/ja00425a051.

10. C. Rossy, E. Fouquet and F.X. Felpin, Beilstein J. Org. Chem., 9, 1426 (2013); https://doi.org/10.3762/bjoc.9.160.

11. E. Fischer and F. Jourdan, Ber. Dtsch. Chem. Ges., 16, 2241 (1883); https://doi.org/10.1002/cber.188301602141.

12. O. Algul, A. Kaessler, Y. Apcin, A. Yilmaz and J. Jose, Molecules, 13, 736 (2008); https://doi.org/10.3390/molecules 13040736

13. J.H. Lee and J. Lee, FEMS Microbiol. Rev., 34, 426 (2010); https://doi.org/10.1111/j.1574-6976.2009.00204.x.

14. B. Bertinetti, M. Scandiani and G. Cabrera, Am. J. Plant Sci., 2, 245 (2011); https://doi.org/10.4236/ajps.2011.22026.

15. A. Kumar, D. Kumar, M. Akram and H. Kaur, Int. J. Pharm. Biol. Arch., 2, 744 (2011).

16. J. Badiger, K. Manjulatha, M. Girish, A. Sharif and M.G. Purohit, ARKIVOC, 217 (2009); https://doi.org/10.3998/ark.5550190.0010.c19.

17. R.K. Grover and J.D. Moore, Phytopathology, 52, 876 (1962). 